\begin{tabular}{c}
\hline OPEN \\
JOURNAL \\
SYSTEMS \\
\hline \hline
\end{tabular}

ISSN:2237-2202
Available on line at Directory of Open Access Journals

Journal of Hyperspectral Remote Sensing v.9, n.4 (2019) 204-216

www.periodicos.ufpe.br/revistas/jhrs

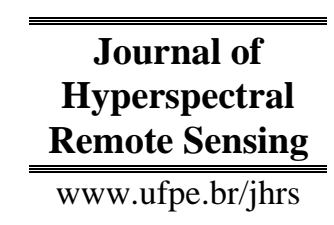

\title{
Spacialization of the degradation risk in the Natural Monument of the São Francisco River
}

\author{
Douglas A. de O. Silva ${ }^{*}$, Suzana M. G. L. Montenegro ${ }^{* *}$, Pabrício M. O. Lopes ${ }^{* * *}$, Gabriel S. T. Fernandes ${ }^{* * * *}$, Ênio F. \\ de F. Silva ${ }^{* * * * *}$, Anderson dos Santos ${ }^{* * * * * *}$, Cicero G. dos Santos
}

\begin{abstract}
*Doutorado em Engenharia Agrícola, Departamento de Engenharia Agrícola da Universidade Federal Rural de Pernambuco - UFRPE, Recife-PE, Brasil. E-mail: douglasalbertosilva@ hotmail.com (autor correspondente)

${ }^{* * *}$ Professora da Universidade Federal de Pernambuco - UFPE, Recife-PE, Brasil

*** Doutor em Sensoriamento Remoto, Professor Adjunto da UFRPE, Recife-PE, Brasil

***** Mestrado em Engenharia Agrícola, Departamento de Engenharia Agrícola da UFRPE, Recife-PE, Brasil

${ }^{* * * * * *}$ Professor associado do Departamento de Engenharia Agrícola da UFRPE, Recife-PE, Brasil

${ }^{* * * * * * *}$ Doutorado em Engenharia Agrícola, Departamento de Engenharia Agrícola da UFRPE, Recife-PE, Brasil

${ }^{* * * * * * * *}$ Professor do Departamento de Agronomia da Universidade Federal de Alagoas-UFAL.
\end{abstract}

Received 21 August 2019; accepted 30 October 2019

\begin{abstract}
Understanding changes related to environmental degradation by parameters such as Normalized Difference Vegetation Index (NDVI), Surface Albedo $(\alpha)$ and Moving Standard Deviation Index (MDSI) has been of great relevance in the study of environmental impacts. The objective of the present study was to analyze the evolution of soil degradation and also of the soil use and occupation in the San Francisco River Natural Monument, using surface data and images from Landsat-5 and Landsat-8, for the 1987, 1997, 2007 and 2017 years. Remote sensing techniques were used to estimate indices such as NDVI, albedo $(\alpha)$ and MDSI. The change detection technique and decision tree classification based on predefined rules in NDVI, albedo and MDSI were applied to infer degradation, soil use and occupation. There was a significant increase in degradation, especially for areas with high degradation. Vegetation indices showed the lowest values for areas of low vegetation and exposed soil, being the highest values found for Caatinga dense vegetation. It was concluded that the change detection technique and decision tree classification were efficient in identifying the degradation during the study period. The change detection technique algorithm was more sensitive to water bodies than the change intensity technique.
\end{abstract}

Keywords: Albedo, Caatinga, landsat, NDVI, conservation units.

\section{Introduction}

Caatinga is considered the most biodiverse dry forest of the world and an exclusively Brazilian biome, in which about 5000 plant species can be found, among which 380 are endemic (Forzza et al., 2012; Siqueira Filho, 2012). However, the natural vegetation of Caatinga has been penalized for the lack of compliance with environmental legislation, given that almost half of the original vegetation of Caatinga has been altered, originating in addition to climatic conditions such as drought events that naturally cause degradation and desertification of the biome, through anthropic actions such as deforestation, burning and also the inadequate management of agricultural activities that together accelerate these processes (IBGE, 2015).

Given these aggravating factors, we highlight the presence of several Integral Protection Conservation Units, in which one of the most prominent is called "São Francisco River Natural Monument", also known as Mona do San Francisco, which is located completely inserted into the Caatinga biome. The San Francisco River Natural Monument is characterized, above all, by the exuberant water mirror of the Xingó Hydroelectric Power Plant lake, belonging to the San Francisco Hydroelectric Company-CHESF, and its surroundings formed by rocky walls, covered by Caatinga vegetation (Freire et al., 2019). 
Monitoring degradation as well as detecting changes of the soil use is crucial for a better understanding of the dynamics of changes in soil coverage. Landsat satellite images are used to identify and evaluate changes in vegetation coverage structure, physiognomy and dynamics, making it possible to study changes in soil coverage at a spatial and temporal scale, at low cost and with better accuracy (Oliveira, 2015; Silva et al., 2016; Silva et al., 2019). Several authors have found that precipitation before the satellite passes affects the spectral response of orbital images (Ponzoni and Shimabukuro, 2010; Caten et al., 2015).

Satellite images are useful tools for identifying and determining the degree of degradation in Caatinga. Degradation analysis can be done using Decision Tree (AD) classification (Ruiz et al., 2014). To map areas at risk of environmental degradation, the AD classifier is used which uses pre-established rules on changes in coverage (vegetation indices), vegetation heterogeneity, Moving Standard Deviation Index (MSDI) and micrometeorological conditions of vegetation, surface albedo. Several authors have studied environmental degradation through the $\mathrm{AD}$ classifier. Xu et al. (2009) used the NDVI, MSDI and surface albedo to evaluate and determine the degree of degradation on the Ordos Plateau in China with images of Landsat-4, 5 and 7 on a regional scale. Caten et al. (2015) used the AD classifier to analyze soil coverage dynamics between 1989 and 2011, in the Marombas river basin, Santa Catarina. Vorovencii (2015) based on albedo, MSDI and Vegetation Index Soil-Adjusted (SAVI) obtained from the Landsat-5 satellite applied the AD classifier to assess the risk of desertification in Romania, in the years 1987 to 2011.

Thus, this study aimed to evaluate and monitor the risk of degradation and soil use change in the San Francisco River Natural Monument, using orbital images of the Landsat-5 sensor TM (Thematic Mapper) and Landsat-8 sensor OLI / TIRS (Operational Land Images / Thermal Infrared Sensor) in the years 1987, 1997, 2007 and 2017.

\section{Material and methods}

Area of study and data used

The study area covers the conservation space of the San Francisco River Natural Monument, located at the coordinates: $08^{\circ} 48^{\prime} 50^{\prime \prime} \mathrm{S}, 40^{\circ} 30^{\prime} 23^{\prime \prime} \mathrm{W} ; 09^{\circ} 05^{\prime}$

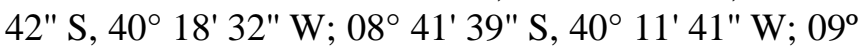
$14^{\prime} 03^{\prime \prime}, 40^{\circ} 11^{\prime} 42^{\prime \prime}$, with an average altitude of $220 \mathrm{~m}$ (Figure 1), inserted in the semiarid region of northeastern Brazil.

Figure 1 shows the spatial map of the study area, San Francisco River Natural Monument, from an image of the Landsat satellite, in RGB composition, and a spatial resolution of $30 \mathrm{~m}$. The image was georeferenced in the Geographic Coordinate System Universal Transversa Mercator (UTM) - DATUM: WGS1984, zone $24 \mathrm{~S}$.

The San Francisco monument is located between five municipalities: Canindé of San Francisco (SE), Delmiro Gouveia (AL), Olho D'Água do Casado (AL), Piranhas (AL) and Paulo Afonso (BA). It has an area of 26,736.30 hectares, entirely inserted in the Caatinga biome, presenting a high floristic and faunistic diversity. It is characterized, above all, by the lush water mirror of the lake of the Xingó Hydroelectric Power Plant, belonging to CHESF, and its surroundings formed by the magnificent rocky walls, covered by Caatinga vegetation (Freire et al., 2015).

\section{Climatic classification of the study area}

According to the Köppen-Geiger climate classification, the Mona of the San Francisco is a region that has a BSw'h', semiarid (hot and dry) climate. The area has a semiarid tropical climate, characterized by low rainfall and poorly distributed during the year, with dry periods of approximately 10 months (Assis, 2000). The rainy season runs from May to June, with most precipitation in May. It has a rainfall between $500 \mathrm{~mm}$ and $700 \mathrm{~mm}$ with an irregular spatial distribution, the temperature fluctuates little, with annual averages of $25^{\circ} \mathrm{C}$, exceeding $27{ }^{\circ} \mathrm{C}$ in the warmer months, and falling to $20^{\circ} \mathrm{C}$ in the coldest months (INPE, 2001). 


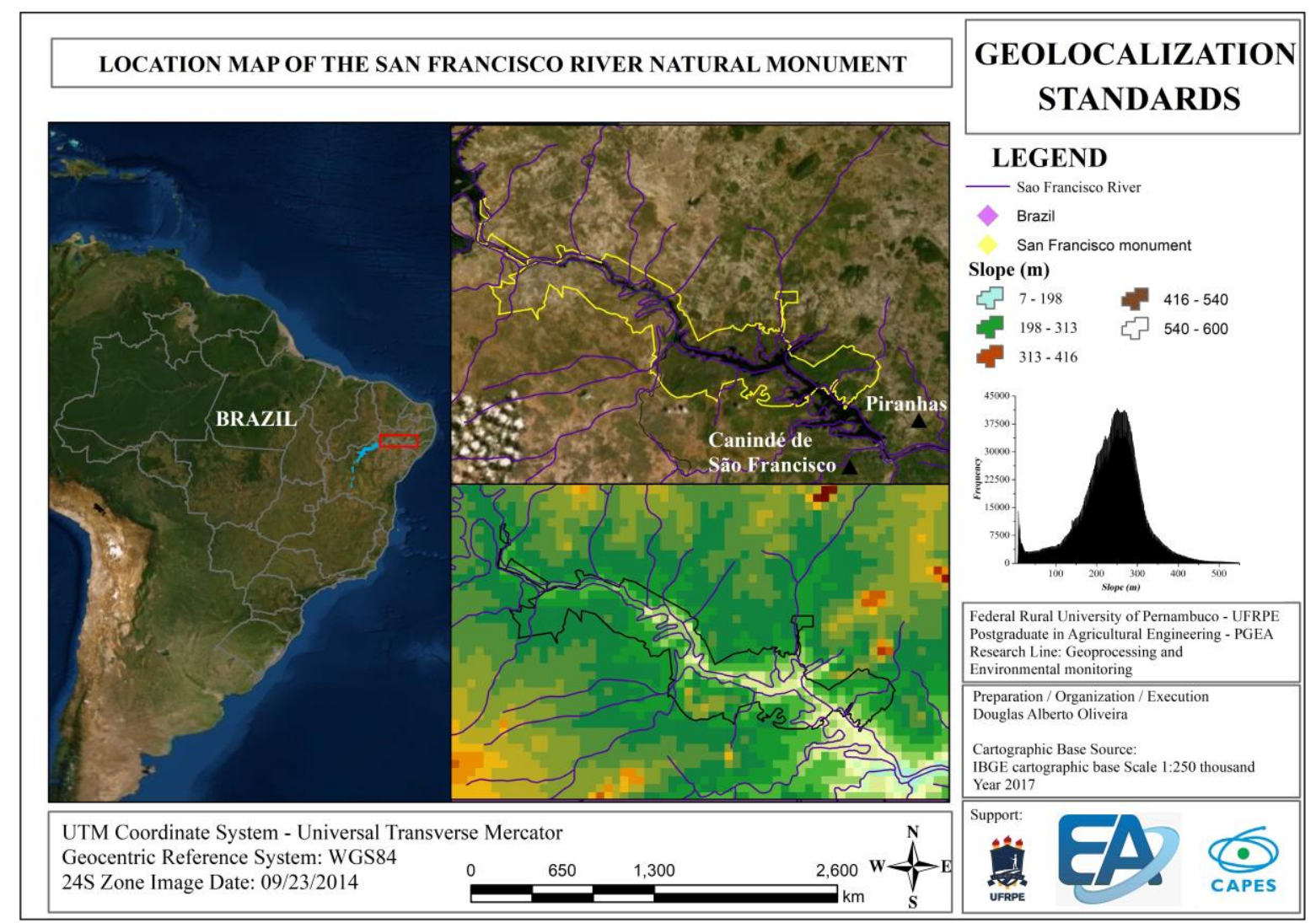

Figure 1 - Spatial map of the study area location, São Francisco River Natural Monument, Northeast Brazil.

\section{Surface weather data}

Surface meteorological data were collected to assist in satellite imagery processing, such as: solar elevation angle $(\mathrm{E})$, air temperature $\left(\mathrm{Tar},{ }^{\circ} \mathrm{C}\right)$, relative air humidity $(\mathrm{RH}, \%)$, atmospheric air pressure (Po, $\mathrm{kPa}$ ), optical depth $(\tau)$ and horizontal visibility (VIS, $\mathrm{km}$ ), essential for image correction (Table 1). Meteorological data were recorded by the National Institute of Meteorology (INMET).

\section{Rain Anomaly Index (RAI)}

The daily rainfall data of the Automatic Meteorological Stations (EMA) of the municipalities of Paulo Afonso-BA located at the geographic coordinates: $9^{\circ} 21^{\prime} 37.51^{\prime \prime} \mathrm{S}$ and $38^{\circ} 12^{\prime} 37.26^{\prime \prime} \mathrm{W}$ and Água Branca-AL located at the geographical coordinates: $9^{\circ} 16^{\prime} 48^{\prime \prime} \mathrm{S}$ and $37^{\circ} 54^{\prime} 00^{\prime \prime} \mathrm{W}$, were made available by the National Institute of Meteorology (www.inmet.gov.br) for the period 1987-2017. Total annual figures from 1987 to 2017 were used to select the extreme years of rainfall using the Rain Anomaly Index (RAI), proposed by Van Rooy (1965) in order to obtain positive and anomalies negative (Equations 1 and 2).

$R A I=3 \times\left[\frac{N-\bar{N}}{M-\bar{N}}\right]$

$R A I=-3 \times\left[\frac{N-\bar{N}}{X-\bar{N}}\right]$

Table 1 - EMA weather variables for Mona do San Francisco.

\begin{tabular}{cccccccc}
\hline Date & JD & E & T & RH & Po & T & VIS \\
\hline $01 / 17 / 1987$ & 17 & 49.23 & 27.4 & 66 & 982.1 & 0.086 & 18.13 \\
$03 / 01 / 1997$ & 60 & 50.33 & 23.2 & 87 & 969.8 & 0.085 & 18.33 \\
$01 / 24 / 2007$ & 24 & 57.07 & 27.4 & 69 & 970.4 & 0.085 & 18.31 \\
$01 / 03 / 2017$ & 03 & 59.12 & 27.4 & 67 & 970.8 & 0.085 & 18.31 \\
\hline
\end{tabular}


Where: current annual precipitation "N" (mm), average precipitation of historical series " $\overline{\mathrm{N}}$ " (mm), average of the ten largest annual precipitations of historical series "M" (mm) and average of the ten lowest annual precipitation of historical series " $\mathrm{X}$ " (mm).

The rainfall regime of the San Francisco river monument was classified according to the RAI methodology, presented in Table 2. The classification elaborated by Van Rooy (1965) was used for dry and rainy years. The classification is made according to the values registered for the RAI, as shown in Table 2.

Table 2 - Rainfall classification according to rainfall anomaly index (RAI).

\begin{tabular}{cc}
\hline $\begin{array}{c}\text { Rainfall anomaly } \\
\text { index (RAI) }\end{array}$ & Rain Classification \\
\hline$>4$ & Extremely rainy (ER) \\
$2>$ and $<4$ & Very rainy (VR) \\
$0>$ and $<2$ & Rainy (R) \\
0 & Neither Rainy nor Dry (NRD) \\
$0>$ and $<-2$ & Dry (D) \\
$-2<$ and $>-4$ & Very Dry (VD) \\
$<-4$ & Extremely Dry (ED) \\
\hline
\end{tabular}

\section{Satellite spatial data}

The three scenes from the Landsat-5 TM and one from the Landsat-8 OLI sensor were purchased from the USGS / NASA website: https://earthexplorer .usgs.gov/, have a spatial resolution of $30 \mathrm{~m}$. The scenes that coverage the study area, have orbit/point $215 / 67$ and 216/66, were chosen in the condition of clear sky with the lowest possible cloud presence $(<10 \%)$ and belonging to the same period of the year, passing over the local time at 09h00 (local time).

Digital processing of multispectral bands of satellite images was initially performed by band stacking and georeferencing in the DATUM UTM Geographic Coordinate System - Zone 24 S, in which the area of the present study is located.

The images were processed in ERDAS IMAGINE® Software 9.1, with the implementation of steps of the Surface Energy Balance Algorithms for Land (SEBAL) (Bastiaanssen, 2000; Allen et al., 2002).

\section{Atmospheric Correction}

The atmospheric correction of the images was performed using the Fast Line-of-sight Atmospheric Analysis of Spectral Hypercubes model (FLAASH) (Felde et al., 2003), informing date, time, place of passage of Landsat-5 and Landsat- 8 model tropical atmospheric, continental aerosol and horizontal atmospheric visibility. The atmospheric horizontal visibility (VIS) was estimated by inverting Equation 3, proposed by Deschamps et al. (1981).

$$
\beta=0.613 \times \mathrm{e}^{-\mathrm{VIS} / 15}
$$

\section{Image Processing}

Surface albedo $(\alpha)$ represents the surface's ability to reflect solar energy, calculated according to Equation 4 (Silva et al., 2016).

$\alpha=-62.2 \times \rho_{2}-57.3 \times \rho_{3}-48.3 \times \rho_{4}-29.5 \times \rho_{5}-7.3 \times \rho_{6}-2.4 \times \rho_{7}$ (4)

Where: $\rho 2, \rho 3, \rho 4, \rho 5, \rho 6$ and $\rho 7$ are the reflectances of each band.

NDVI indicates the degree of photosynthetic activity of healthy vegetation, being estimated according to Equation 5.

$$
\mathrm{NDVI}=\frac{\rho_{5}-\rho_{4}}{\rho_{5}+\rho_{4}}
$$

The MSDI corresponds to the standard deviation calculated using a $3 \times 3$ filter applied to Landsat- 5 band 3 and Landsat- 8 band 4 , according to Equation 6.

$$
\text { MSDI }=\sqrt{\frac{\sum_{\mathrm{i}=1}^{\mathrm{n}}\left(\mathrm{DN}_{\mathrm{i}}-\overline{\mathrm{DN}_{\mathrm{i}}}\right)^{2}}{\mathrm{~N}}}
$$

Where: $\mathrm{N}=$ number of filter pixels $3 \times 3$, ie $\mathrm{N}$ $=9 ; \mathrm{DNi}=$ pixel value $\overline{D N \imath}=$ value of the average digital number of each nine pixel window.

The thematic maps of environmental degradation of the San Francisco river monument were estimated from the classification by AD based on preestablished rules. Indicator rule sets for each environmental degradation class are listed in Table 3 as $\mathrm{Xu}$ et al. (2009). The nonexistent, low, and severe degradation classes were accurately identified using only NDVI and albedo. MSDI was mainly used to distinguish medium and high degradation. 
Table 3 - Rule for degradation evaluation using Landsat-5 and Landsat-8 images. Source: Adapted from Xu et al. (2009) and Silva et al. (2019).

\begin{tabular}{cccc}
\hline \multirow{2}{*}{ Degradation Classes } & \multicolumn{3}{c}{ Indexes } \\
\cline { 2 - 4 } & NDVI & MSDI & Albedo \\
\hline \multirow{2}{*}{ Nonexistent } & $<0.25$ & --- & $<0$ \\
Low & $<0.50$ & --- & --- \\
Medium & $<0$ & & $>0$ \\
& $0.32<\mathrm{e}<0.40$ & $>3$ & $0.175<\mathrm{e}<0.19$ \\
High & $0.32<\mathrm{e}<0.40$ & $<3$ & $0.175<\mathrm{e}<0.19$ \\
Severe & $0.25<\mathrm{e}<0.32$ & $>3$ & $0.175<\mathrm{e}<0.19$ \\
& $0.25<\mathrm{e}<0.32$ & $<3$ & $0.175<\mathrm{e}<0.19$ \\
& $<0.25$ & --- & $>0.22$ \\
\hline
\end{tabular}

The intensity of change in soil use and occupation (I) was calculated from the reflectance values of Landsat- 5 bands 3 and 4 and Landsat -8 bands 4 and 5 at time 1 (analyzed month) and time 2 (month after the analysis) expressed by Equation 7 (Zhan et al., 2000).

$$
\mathrm{I}=\sqrt{\left(\Delta \rho_{4}\right)^{2}+\left(\Delta \rho_{5}\right)^{2}}
$$

\section{Results and discussion}

\section{Rainfall anomaly index (RAI)}

Figure 2 shows the annual IAC values for the post studied. It is possible to observe a period of five consecutive years of drought from 2010 to 2014; and a period of three consecutive years of drought: two weaker years (1990 and 1991) and the strongest one
(1992). It is possible to observe a period of three consecutive years of rain between 2015 and 2017. The values calculated for annual RAI ranged from -5 to +9 . Alves et al. (2016), studying the municipality of Petrolina, using data from 1964 to 2007, found ACI values similar to those in this study ranging from -5.31 to +7.24 .

Figure 2 shows that only 1989 and 2017 are considered to be "extremely rainy" (above 4.0), coinciding with the effect of La Niña. Considering the perspective of the considered "dry years", only the year 2012 of the analyzed series was "extremely dry". However, the years 1987 (Moderate El Niño), 1993 (Moderate El Niño), 1998 (Moderate El Niño), 2001 (Moderate La Niña), 2003 (Moderate El Niño), 2011 (Moderate La Niña), 2013 (Moderate El Niño) and 2014 (Moderate El Niño) are classified by the RAI as "very dry".

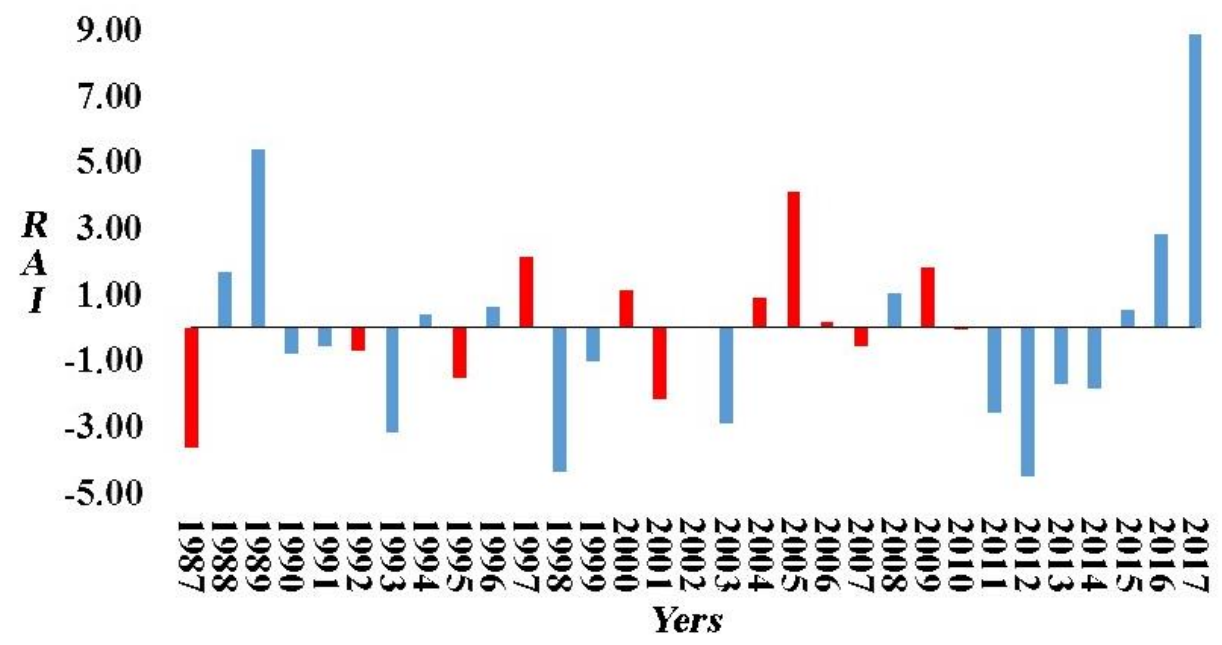

Figure 2 - Annual Rainfall Anomaly Index (RAI) of the post studied, for the consecutive period from 1987 to 2017. 


\section{Soil use and occupation}

Figure 3 shows the elements that make up the spatial organization of the San Francisco River Natural Monument.

From this, an analysis can be made of the spatial variability of these elements and the relationship of this distribution to the situation of the main riverbed. There was great intensity in agricultural activities to northwest of the monument, as well as the growth of pasture areas are observed mainly in the adjacent regions northeast of the monument. The predominant areas of caatinga showed, over time, have been reduced and replaced by pasture areas, resulting from anthropic pressure exerted in the region.

The municipalities that make up the monument area have been undergoing a transformation process articulated with the historical moment of the region's capitalist mode of production. In this context, it redefines the production and function of space, consolidating itself in a region specialized especially in agriculture and tourism, mainly in ecotourism.

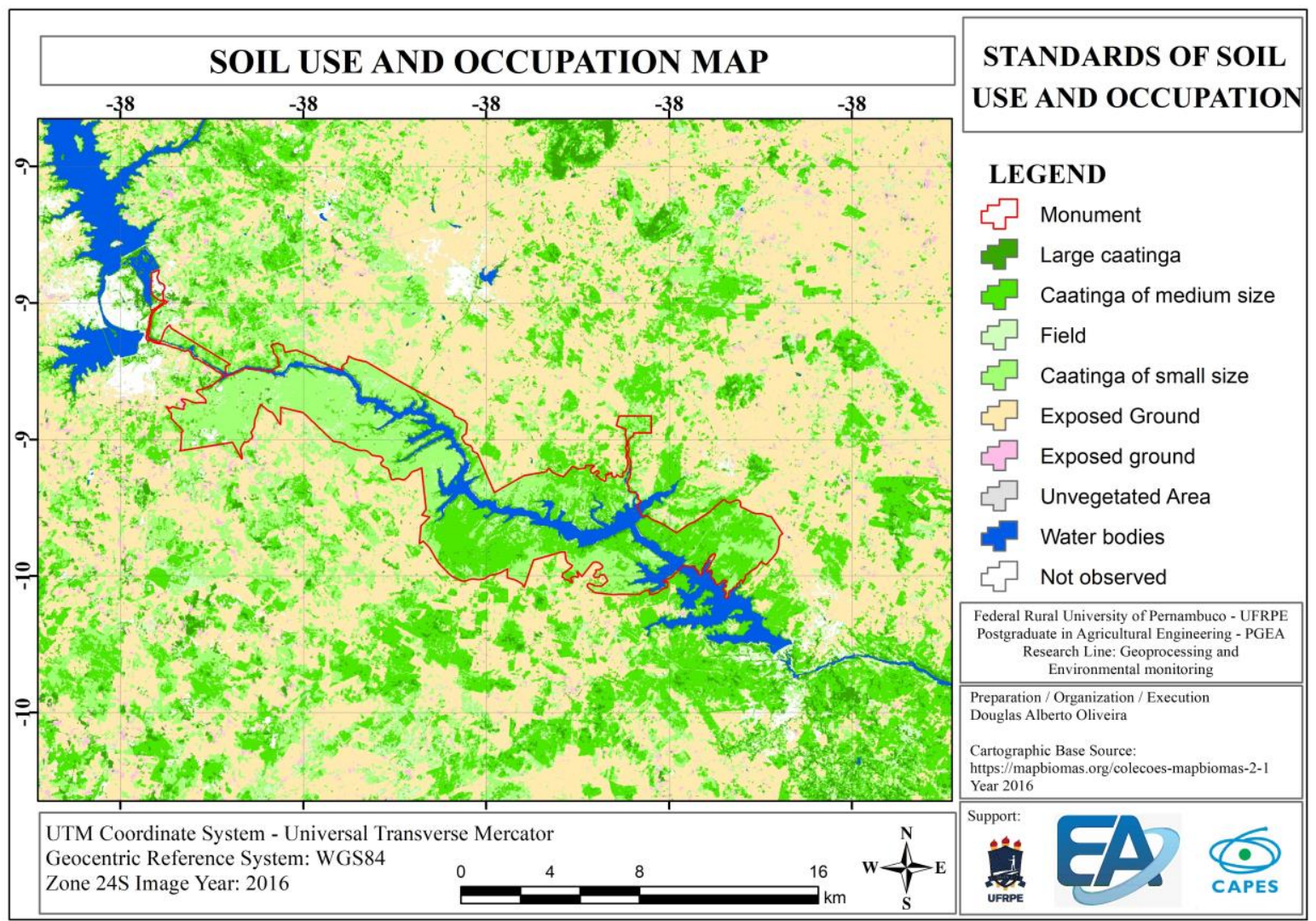

Figure 3 - Map of land use and occupation of the São Francisco River Natural Monument.

\section{Vegetation Indexes}

The thematic maps of Figures 4 and 5 highlight the behavior of vegetation in 1987, 1997, 2007 and 2017. The NDVI and SAVI vegetation indices are good indicators of vegetation in the locality, allowing to analyze and monitor the areas in an increasing process of degradation and desertification, since vegetation indices show the spectral behavior of vegetation in relation to the soil and other different surface targets (Cunha et al., 2012). In this sense, the following thematic maps (NDVI and SAVI) present different answers for the different soil uses and occupations the region, favoring the quantitative and spatial in observation of the types of soil coverage.

Based on Figure 4, it can be seen that the 1997 NDVI map, on average, shows the highest vegetation coverage values, viewed mainly near the control point $3\left(9^{\circ} 28^{\prime} 11.4^{\prime \prime} \mathrm{S}, 38^{\circ} 04^{\prime} 39.1^{\prime \prime} \mathrm{W}\right)$. This year is classified as rainy (Figure 2). Accumulated rainfall (three months before the Landsat-5 crossing dates) amounts to $145.3 \mathrm{~mm}$, contributing to greater Caatinga photosynthetic activity. According to Arraes et al. (2012) rainfall indices have a strong influence on water balance in the Caatinga biome as well as soil moisture, directly influencing NDVI and SAVI. 


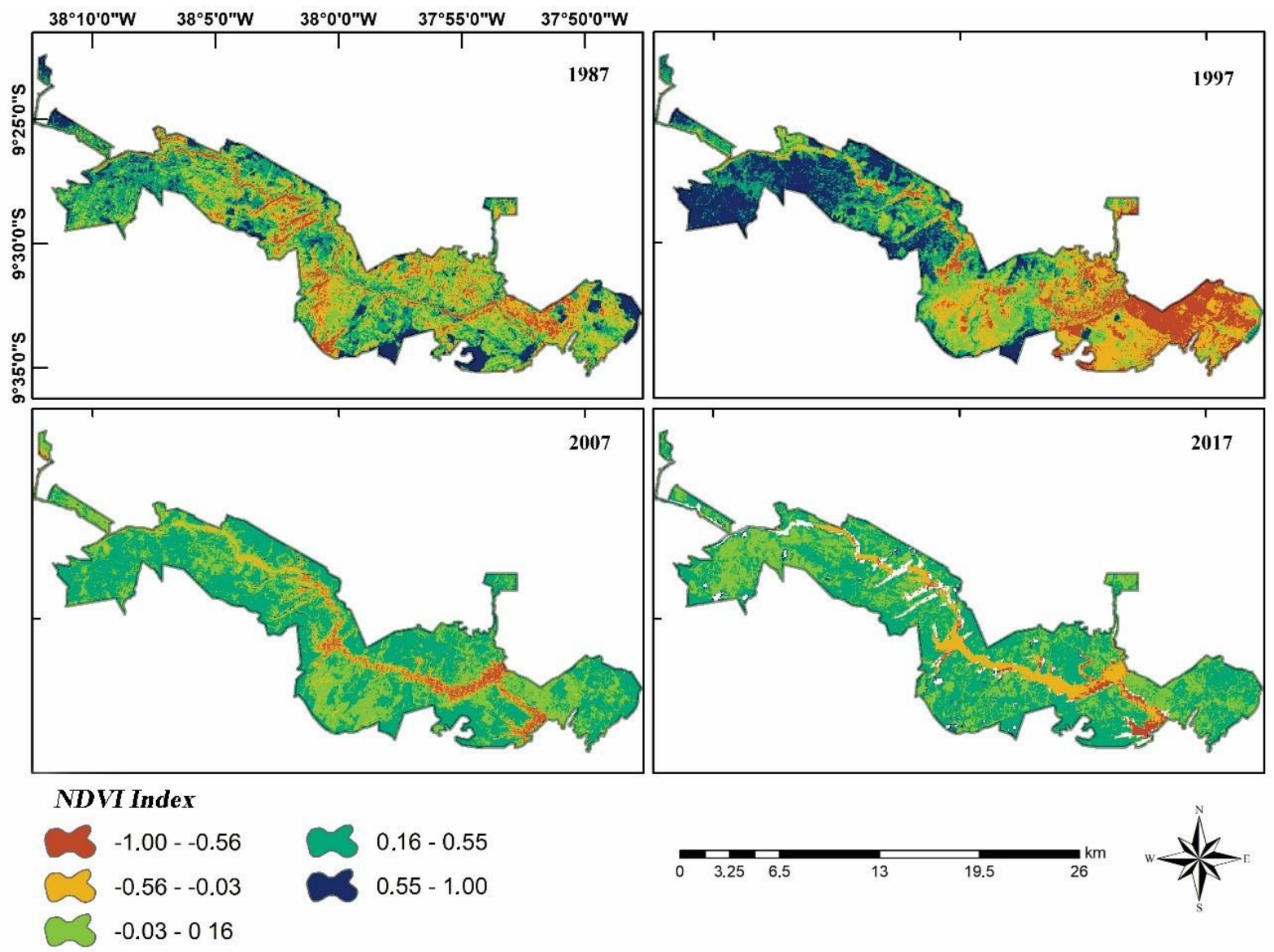

Figure 4 - Temporal and spatial evolution of Normalized Difference Vegetation Index (NDVI) in the San Francisco River Natural Monument from 1987 to 2017.

The results of the evaluation of the SAVI of 1987, 1997, 2007 and 2017 are presented in Figure 5. In general, given the spatial-temporal analysis, the values of NDVI and SAVI vary between -1 and +1 , where the Higher values can be observed in the dark blue tones, followed by the light green and dark tones, where they are usually areas that have dense vegetation and/or cultivated areas, favoring the increase of index values. However, in the red and light yellow tones, areas with water bodies are observed, which have negative values.

For such indices, positive values close to zero indicate areas of exposed soil or sealed areas. However, it is noteworthy that NDVI and SAVI respond proportionally to precipitation, thus directly influencing their values in these events, since the region under study is predominantly covered by Caatinga vegetation, which has a high resilience power (Rodrigues et al., 2009; Arraes et al., 2012).

SAVI maps corroborate with those of NDVI (Figure 4) since, as with NDVI, the highest SAVI values are found in the northwest region of the San Francisco river natural monument, however, the lowest values are observed in the southeast region (Figure 5). Similar results were found by Silva et al. (2019) in a study of Caatinga in the lower San Francisco region. 


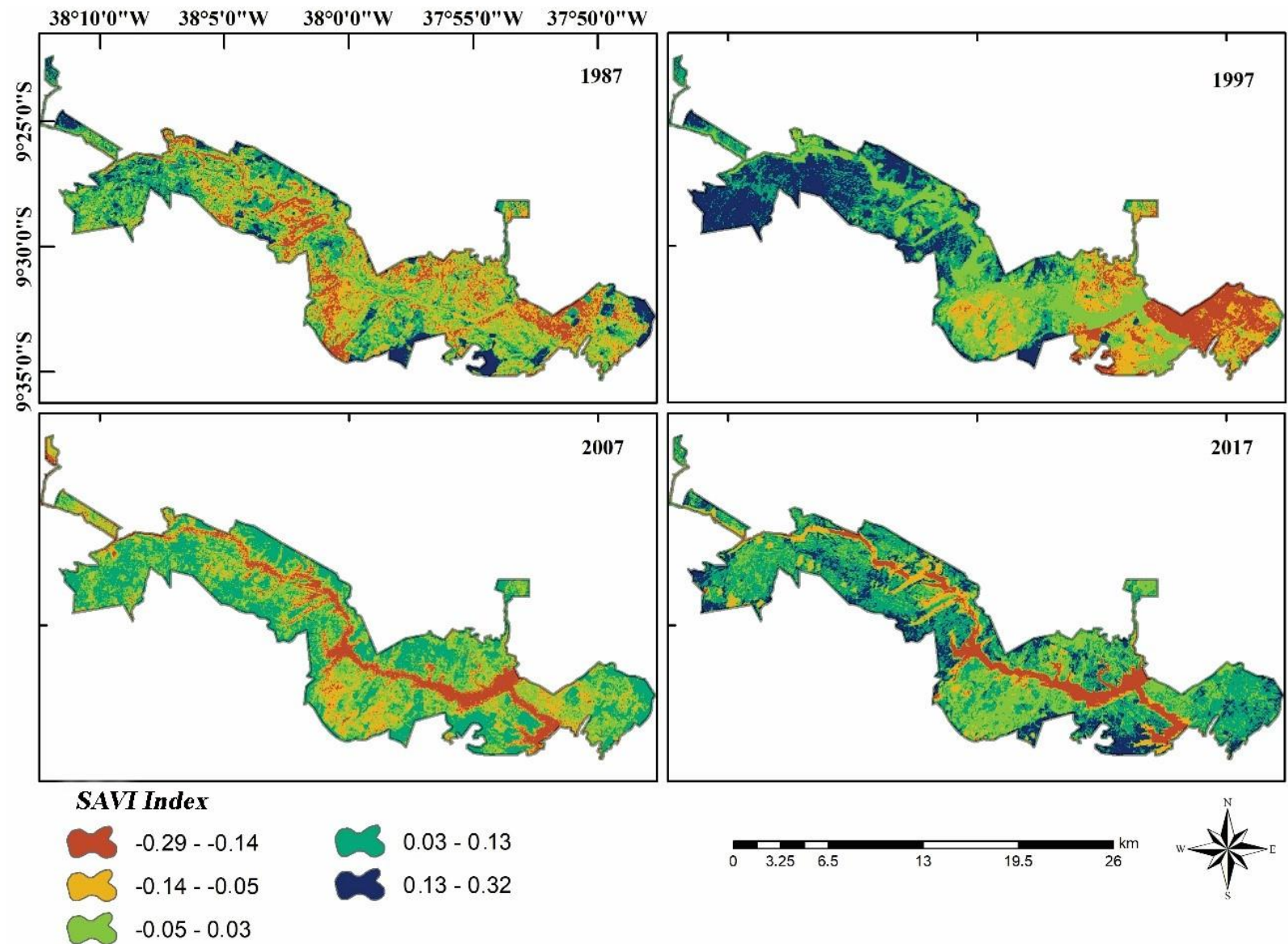

Figure 5 - Temporal and spatial evolution of Vegetation Index Soil-Adjusted (SAVI) in the San Francisco River Natural Monument from 1987 to 2017.

\section{Surface albedo}

The results of the evaluation of the albedo of 1987, 1997, 2007 and 2017 are presented in Figure 6. In general analysis, different shades are observed for the pixels of the surface albedo thematic map, as shown in Figure 6. albedo ranges from 0.0 to 0.69 , and the areas of water bodies, represented by the dark blue hue, present the lowest values, the largest stand out in relation to the dark yellow color and especially the red one, in which denote waterproofed areas with little or no vegetation. Some points can be observed the presence of clouds, which justifies the maximum albedo value of 0.69 . Monitoring such a parameter is extremely important given the understanding and identification of climate change, degradation, desertification, burning and environmental impacts as a whole caused to the environment constantly (Silva et al., 2005).

Thus, given the spatiotemporal analysis of albedo, in 1987, 1997, 2007 and 2017, it is explained by its average increase, the growth of exposed soil areas, motivated by the different uses and occupations of the soil, especially the expansion of urban areas over time and the possible inadequate management of irrigated agriculture, which favors the process of soil degradation and the consequent desertification of the areas. 


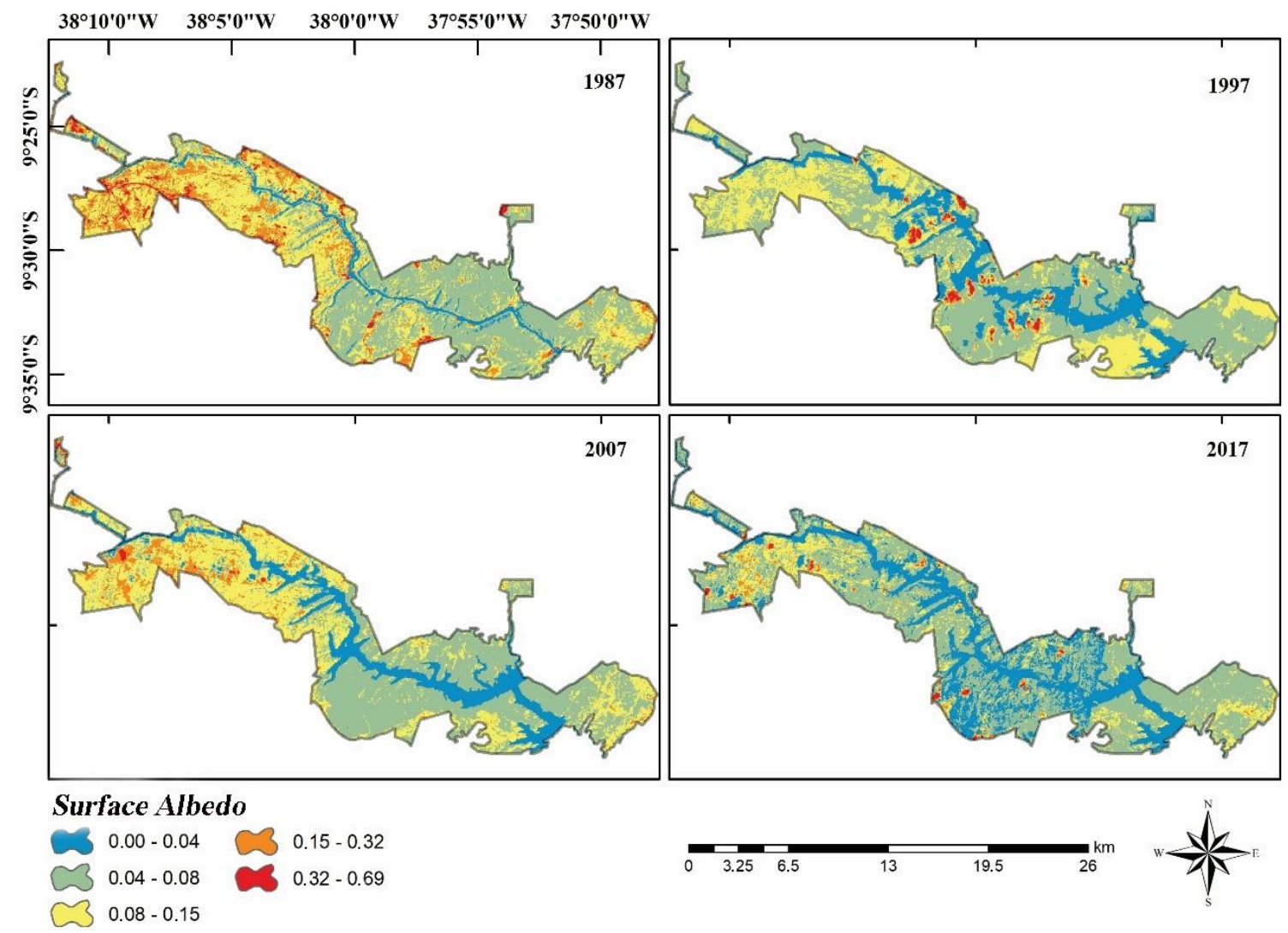

Figure 6 - Temporal and spatial evolution of the albedo in the San Francisco River Natural Monument from 1987 to 2017.

\section{Environmental degradation}

The results of the degradation assessment in 1987, 1997, 2007 and 2017 are shown in Figure 7. It is found that the degradation has a tendency of inversion. This fact is observed in the analysis of the degradation maps of 1997 and 2007 (Figures 7B and C, respectively), in which from 1987 to 1997 there was an increase in degradation, especially for the upper class, viewed mainly near the control point $1\left(9^{\circ} 33^{\prime} 07.8^{\prime \prime} \mathrm{S}\right.$, $\left.37^{\circ} 51^{\prime} 21.1^{\prime \prime} \mathrm{W}\right)$ and checkpoint 2 (9 $9^{\circ} 34^{\prime} 15.7^{\prime \prime} \mathrm{S}, 37^{\circ}$ $\left.52^{\prime} 23.2^{\prime \prime} \mathrm{W}\right)$. However, when comparing 2007 with 1997, there is a reversal of degradation, with a reduction, mainly, in the nonexistent, low and medium classes.

The amount of rainfall in the three months before imaging increased in $1997(181.1 \mathrm{~mm})$ compared to 2007 (19 $\mathrm{mm})$, associated with the $\mathrm{La}$ Niña phenomenon which for 1997 was classified as strong (Alves et al., 2016). The intensity of precipitation can cause superficial or deep erosion and leaching of toxic substances such as bauxite, clay, slime, pyrites and rudimentary soil forms. This erosion can be aggravated in areas such as the San Francisco natural monument that have areas with steep declivity. These actions result in loss of vegetation and barren soil coverage with increased reflectance and albedo elevation (Vorovencii, 2015).

The 2007 map (Figure 7C) shows most of the San Francisco River monument with low degradation. This class, which covers the low levels of risk of soil degradation levels, has the representative sectors, occupying most of the studied area. From these observations, it can be inferred that on the imaging date, the studied area offers less risk to the degradation process. This fact is due to precipitation as well as resilience, which are factors that influence the formation and maintenance of Caatinga. It is observed that the wine-toned class corresponds to the severe class, which represents the pixels with the lowest NDVI values and the highest albedo and MSDI values, with low representation in all studied years (Figure 7). It is noted that for the year 1997 the degradation is more concentrated in the southeast part of the monument of the San Francisco river, this fact may be associated with the proximity to the cities of Olho d'água do Casado-AL, Piranhas-AL and Canindé de São Francisco-SE.

The scenic beauty of the area is intensely harnessed by the growing tourism industry mainly in the Xingó region. There are also other economic 
activities of great ecological impact in the region, such as the cultivation of fish in net-tanks, as well as social conflicts caused by invasions of protected areas within the protected area (UC) carried out by members of the labor movement-earth MST (Freire et al., 2019).

It was also observed in the study area that the degradation maps are in accordance with the NDVI and SAVI maps (Figures 4 and 5, respectively), in which there is no vegetation coverage in the upper class areas (southeast region of the San Francisco river monument), contributing to a greater susceptibility to erosion.

Reduction of vegetation coverage on dry surfaces affects surface temperature and air humidity, influencing air mass circulation and precipitation at the San Francisco River monument. In addition, low soil moisture and reduced soil layers favor wind erosion in places with exposed soil (Vorovencii, 2015).

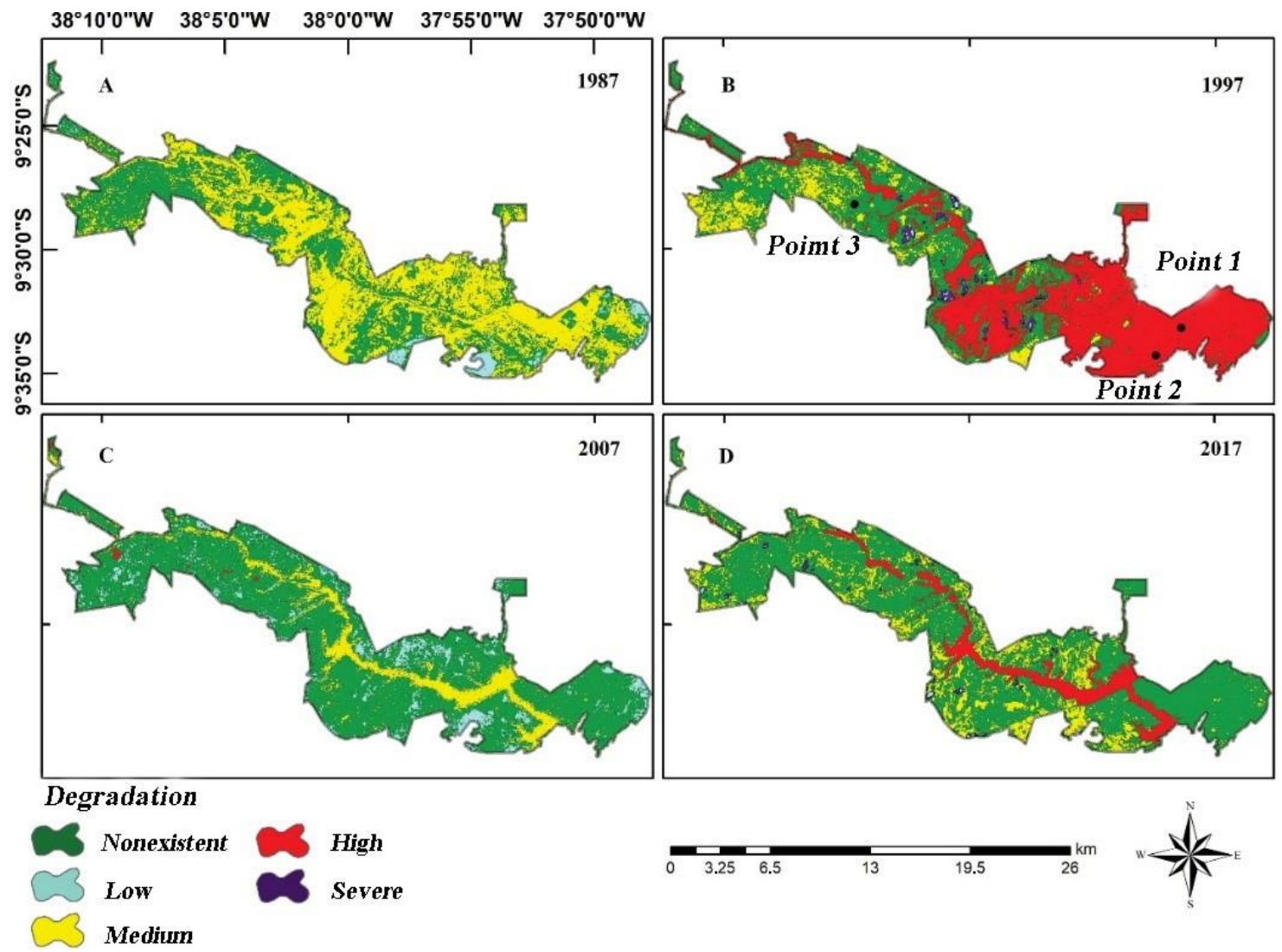

Figure 7 - Temporal and spatial evolution of degradation in the San Francisco River Natural Monument from 1987 to 2017.

Table 4 presents the accuracy values and the Kappa Index which shows the accuracy and confidence level of the risk of degradation maps in the studied classes. Analyzing the accuracy (Table 4), it can be seen that the classification results obtained were satisfactory with an average accuracy of $98.95 \%$, the best accuracy was found in 1997 with an accuracy of 99.7\%. Considering the kappa index, an average value of 0.96 was found; The highest value found was 0.99 in 2017 and the lowest was 0.90 in 1987.

Based on Table 4, the total Kappa Index values found were considered excellent for all images.
Demarchi et al. (2011), using Landsat-5 images, analyzed surface changes, thus obtaining Kappa values well below those found in this study, 0.57 rated "good" to 0.74 "very good" quality respectively.

Accuracy indices (Table 4) indicate that for 1997, 99\% of the classes analyzed in the image were correctly identified by the classifier, ie $99.7 \%$ of the pixels were correctly marked to their field truth and actually corresponded to the classes studied on the map. The biggest confusion in TM image classification occurred for 2007. Oliveira (2015), analyzing forest area, found indices below those found in this study. 
Table 4 - Kappa Index and Accuracy Values in the San Francisco River Natural Monument from 1987 to 2017.

\begin{tabular}{ccc}
\hline Year & Kappa & Accuracy \\
\hline 1987 & 0.90 & 98.4 \\
1997 & 0.98 & 99.7 \\
2007 & 0.98 & 98.2 \\
2017 & 0.99 & 99.5 \\
\hline
\end{tabular}

\section{Change Detection}

The detection images allow highlighting the areas with reduced Caatinga coverage in the San Francisco river natural monument in the years analyzed. Water bodies are mostly classified as high change, while intensity change maps (Figure 8) show no change. It is observed that the change detection technique algorithm is more sensitive to water bodies than the change intensity technique algorithm, since in the change detection maps the water bodies of almost every month analyzed are classified as high shift (Figure 8).

Figure 8A shows the predominance of the upper class that occurs throughout almost the southeast region of the image in the natural monument of the San Francisco river. The severe class, despite being identified, is imperceptible, with small isolated areas viewed mainly near control point $2\left(9^{\circ} 34^{\prime} 15.7^{\prime \prime} \mathrm{S}, 37^{\circ}\right.$ 52' 23.2" W) (Figure 8F).

These results corroborate those found by Ribeiro et al. (2014), which detected changes in Caatinga soil and vegetation through spectral images in the city of Sumé-PB.

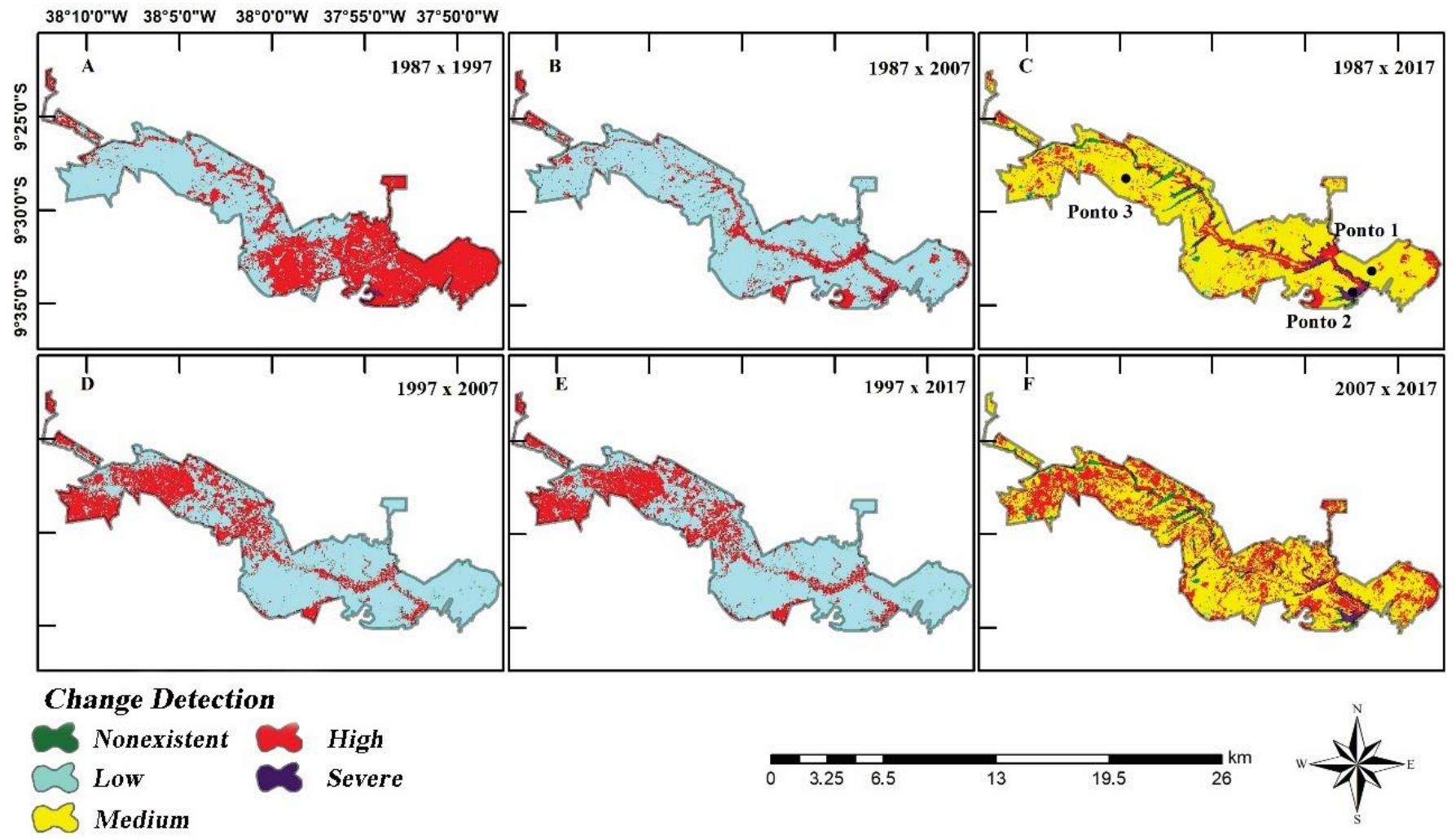

Figure 8 - Temporal and spatial evolution of change detection in the San Francisco River Natural Monument from 1987 to 2017.

\section{Intensity of change}

The results of the assessment of the intensity of change of the years 1987, 1997, 2007 and 2017 are presented in Figure 9. It is observed that Figure 9F, which corresponds to the years 2007 and 2017 compared to the other images, presents larger areas classified as High (red hue) change viewed mainly near control point $3\left(9^{\circ} 28^{\prime} 11.4^{\prime \prime} \mathrm{S}, 38^{\circ} 04^{\prime} 39.1^{\prime \prime} \mathrm{W}\right)$, indicating that when compared to 2007 and 2017 there are major changes mainly in the Caatinga areas driven by low rainfall. It can be observed that between the image of the previous year "2007" and the subsequent year " 2017 " the annual rainfall is only $477 \mathrm{~mm}$ and $1168.1 \mathrm{~mm}$ respectively, a value considered high for 2017. 


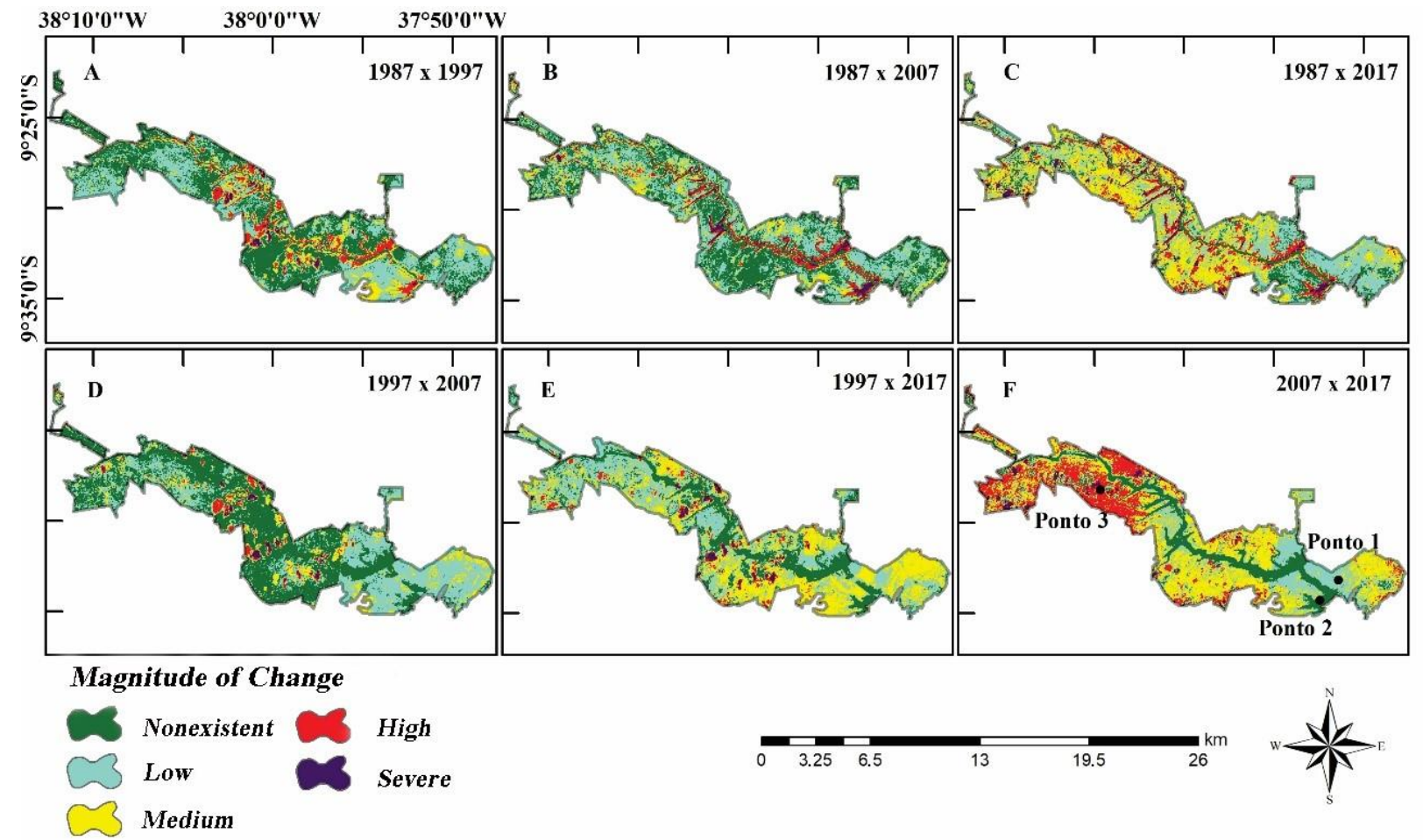

Figure 9 - Temporal and spatial evolution of the intensity of change in the San Francisco River Natural Monument from 1987 to 2017.

Corroborating these results Zhan et al. (2000) also related low rainfall as the main factor in the presence of high and severe change classes in the studied areas. This behavior is partly explained by the fact that 2017 is classified as a rainy year, as Caatinga has great resilience. In Caatinga, the recomposition of vegetation occurs quickly with the arrival of the first rains (Maldonado, 2005).

\section{Conclusions}

The classification of soil coverage by NDVI, albedo and MSDI based AD algorithm, as indicators of vegetation coverage conditions and surface heterogeneity, allowed the identification of different coverages with a Kappa index above $95 \%$ in the studied period.

Changes in the degree of degradation were identified with increased albedo and reduced NDVI.

The processes of change detection and intensity of change demonstrated modifications of the San Francisco natural monument in the period of the years 1987-2017.

\section{Acknowledgment}

The Federal Rural University of Pernambuco; Graduate Program in Agricultural Engineering;
Department of Agronomy; The study was conducted with support from the Higher Education Personnel Improvement Coordination Brazil (CAPES), Financing Code 001; National Council for Scientific and Technological Development (CNPq); NASA / USGS for providing satellite spatial data and National Institute of Meteorology (INMET) for surface meteorological data

\section{References}

Allen, R.G., Morse, A., Tasumi, M., Trezza, R., Bastiaanssen, W., Wright, J.L., Kramber, W., 2002. Evapotranspiration from a satellite-based surface energy balance for Snake Plain aquifer in Idaho. The meeting of Unite States Committee on Irrigation, Drainage, and Food Control. San Luis Obispo.

Alves, J.O., Pereira, P.C., Queiroz, M.G., Silva, T.G.F., Ferreira, J.M.S., Araújo Júnior, G.N., 2016. Índice de anomalia de chuva para diferentes mesorregiões do Estado de Pernambuco. Revista Pensar Acadêmico 14, 37-47.

Arraes, F.D.D., Andrade, E.M., Silva, B.B., 2012. Dinâmica do balanço de energia sobre o açude Orós e suas adjacências. Revista Caatinga 25, 119-127. 
Assis, J.S., 2000. Biogeografia e conservação da biodiversidade. Projeções para Alagoas. Maceió.

Bastiaanssen, W.G.M., 2000. SEBAL - based sensible and latent heat fluxes in the irrigated Gediz Basin, Turkey. Journal of Hydrology 229, 87-100.

Caten, A.T., Safanelli, J.L., Ruiz, L.F.C., 2015. Mapeamento multitemporal da cobertura de terra, por meio de árvore de decisão, na bacia hidrográfica. Revista Engenharia Agrícola 35, 11981209.

Cunha, J.E.B.L., Rufino, I.A., Silva, B.B., Chaves, I.D.B., 2012. Dinâmica da cobertura vegetal para a Bacia de São João do Rio do Peixe, PB, utilizandose sensoriamento remoto. Revista Brasileira de Engenharia Agrícola e Ambiental 16, 539-548.

Demarchi, J.C., Piroli, E.L., Zimback, C.R.L., 2011. Analise temporal do uso do solo e comparação entre os índices de vegetação NDVI e SAVI no município de Santa Cruz do Rio Pardo-SP usando imagens LANDSAT-5. Raega 21, 234-271.

Deschamps, P.Y., Herman, M., Tanré, D., 1981. Influence de l'atmosphère en télédétection des ressources terrestres: modélisation et possibilités de correction. Colloque de la Société Internationale de Photogrammétrie et de Télédétection.

Felde, G.W., Anderson, G.P., Cooley, T.W., Matthew, M.W., Adler, G.S.M., Berk, A., Lee, J., 2003. Analysis of Hyperion data with the FLAASH atmospheric correction algorithm. International Geoscience and Remote Sensing Symposium. Proceedings (IEEE Cat. No.03CH37477) 1, 90-92.

Forzza, R.C., Baumgratz, J.F.A., Bicudo, C.E.M., Canhos, D.A., Carvalho Jr, A.A., Coelho, M.A,N., Lohmann, L.G., 2012. New Brazilian floristic list highlights conservation challenges. BioScience 62, $39-45$.

Freire, N.C.F., Moura, D.C., Silva, J.B., Moura, A.A.A., 2019. Mapeamento e análise espectrotemporal das unidades de conservação de proteção integral da administração federal no bioma Caatinga. Recife.

IBGE. Instituto Brasileiro de Geografia e Estatística, 2015. Manual Técnico da Vegetação Brasileira. 2. ed. Rio de Janeiro.

INPE. Instituto Nacional de Pesquisas Espaciais, 2001. (Boletim Meteorológico, 3).

Maldonado, F.D., 2005. Desenvolvimento e avaliação de uma metodologia de detecção de mudanças na cobertura vegetal do semiárido. Tese (Doutorado). São José dos Campos, INPE.

Oliveira, C.P., 2015. Modelagem dinâmica da cobertura florestal do Município de Floresta - PE.
Dissertação (Mestrado). Recife, UFRPE.

Ponzoni, F.J., Shimabukuro, Y.E., 2010. Sensoriamento Remoto no Estudo da Vegetação. Editora Parêntese, São José dos Campos.

Ribeiro, G.N., Francisco, P.R.M., Moraes, J.M., 2014. Detecção de mudança de vegetação de Caatinga através de geotecnologias. Revista Verde 9, 84-94.

Rodrigues, J.D., Andrade, E.D., Teixeira, A.D.S., Silva, B.D., 2009. Sazonalidade de variáveis biofísicas em regiões semiáridas pelo emprego do sensoriamento remoto. Engenharia Agrícola 29, 452-465.

Ruiz, L.F.C., Tem, C.A., Dalmolin, R.S.D., 2014. Árvore de decisão e a densidade mínima de amostras no mapeamento da cobertura da terra. Revista Ciência Rural 44, 1001-1007.

Silva, D.A.O., Lopes, P.M.O., Moura, G.B.A., França E Silva, E.F., Silva, J.L.B., Bezerra, A.C., 2019. Evolução espaço-temporal do risco de degradação da cobertura vegetal de Petrolina-PE. Revista Brasileira de Meteorologia 34, 1-11.

Silva, B.B., Braga, A.C., Braga, C.C., Oliveira, L.M.M., Montenegro, S.M.G.L., Barbosa Junior, B., 2016. Procedimentos para cômputo do albedo com imagens OLI-Landsat 8: aplicação ao semiárido brasileiro. Revista Brasileira Engenharia Agrícola Ambiente 20, 3-8.

Silva, B.B., Lopes, G.M., Azevedo, P.V., 2005. Determinação do albedo de áreas irrigadas com base em imagens Landsat 5-TM. Revista Brasileira de Agrometeorologia 13, 201-211.

Siqueira Filho, J.A. (Org.), 2012. Flora das Caatingas do Rio São Francisco: história natural e conservação. Andrea Jakobsson, Rio de Janeiro, UNIVASF, Petrolina.

Van Rooy, M.P., 1965. A rainfall anomaly index independent of time and space. Notes 14, 43-48.

Vorovencii, I., 2015. Assessing and monitoring the risk of desertification in Dobrogea, Romania, using Landsat data and decision tree classifier. Journal of Environmental Monitoring and Assessment 187, 154-220.

Xu, D., Kang, X., Qiu, D., Zhuang, D., Pan, J., 2009. Quantitative Assessment of Desertification Using Landsat Data on a Regional Scale: A Case Study in the Ordos Plateau, China. Sensors 9, 1738-1753.

Zhan, X., Defries, R., Townshend, J. R. G., Dimiceli, C., Hansen, M., Huang, C., Sohlberg, R., 2000. The $250 \mathrm{~m}$ global land cover change product from the Moderate Resolution Imaging Spectroradiometer of NASA's Earth Observing System. International Journal of remote sensing 21, 1433-1460. 